\title{
MECHANISM OF DNA DEGRADATION INDUCED BY NEOCARZINOSTATIN IN BACILLUS SUBTILIS
}

\author{
Kenzo Ohtsuki and NaKao Ishida \\ Department of Bacteriology, Tohoku, University \\ School of Medicine, Sendai, Japan \\ (Received for publication December 2, 1974)
}

\begin{abstract}
When logarithmically growing Bacillus subtilis cells were exposed to the antitumor protein, neocarzinostatin (NCS), at a concentration of $50 \mu \mathrm{g} / \mathrm{ml}$, cellular DNA was gradually degraded into an acid-soluble form (up to $60 \%$ of total DNA). The degradation appeared to initiate at the growing regions of DNA and to proceed sequentially from the nascent regions to preexistent DNA. Concomitantly with, or perhaps as a consequence of, the degradation of growing regions, DNA detached from the cell membrane and started to show single-strand nicks within 30 minutes after exposure of the cells to NCS, whereas double-strand scission in the DNA became detectable in about 90 minutes. Such endonucleolytic breaks in DNA eventually gave rise to the formation of double-stranded DNA fragments of a single-size class (30-S) as determined by sedimentation in either neutral or alkaline sucrose gradients. In contrast to previous results with Sarcina lutea, the NCS-induced DNA degradation was stimulated by chloramphenicol in B. subtilis and the DNA fragment were not the final breakdown products, but were further degraded into acid-soluble materials.
\end{abstract}

Neocarzinostatin (NCS), an antitumor antibiotic isolated from a culture filtrate of Streptomyces carzinostaticus, is an acidic protein with a molecular weight of $11,000^{1,2)}$ daltons. The antibiotic was found to inhibit specifically the synthesis of DNA in bacterial and mammalian cells ${ }^{3,4)}$ and to induce the degradation of DNA in Sarcina lutea ${ }^{4,5)}$. The NCS-induced DNA degradation in $S$. lutea appeared to require the synthesis of a new RNA and protein since the degradation was prevented by the addition of either actinomycin $\mathrm{D}$ or puromycin ${ }^{5)}$.

In the present paper, we describe the NCS-induced DNA degradation in Bacillus subtilis which differs from $S$. lutea in that the DNA degradation is induced only at high concentrations $(>50 \mu \mathrm{g} / \mathrm{ml})$ of NCS and is not prevented by chloramphenicol but rather stimulated.

\section{Materials and Methods}

Bacterial strain and medium:

Bacillus subtilis PCI-219 was used throughout and the cells were grown at $37^{\circ} \mathrm{C}$ in Tripticase Soy Broth (TSB; Baltimore Biol. Lab., Baltimore). The doubling time of the cells was 45 minutes under these conditions.

Chemicals:

NCS was a gift from Kayaku Antibiotic Research Co., (Tokyo). Sodium N-lauroyl sarcosinate (sarkosyl), sodium dodecyl sulfate, 1,4-bis-[2-(5-phenyloxazolyl)] benzene and 2,5diphenyloxazole were obtained from Wako Pure Chemical Industries, Ltd., (Osaka). [6- $\left.{ }^{3} \mathrm{H}\right]$ Thymidine $(14.0 \mathrm{Ci} / \mathrm{mmole})$ and $\left[2-{ }^{14} \mathrm{C}\right]$ thymidine $(51.0 \mathrm{mCi} / \mathrm{mmole})$ were purchased from Daiichi Pure Chemicals Co., Ltd., (Tokyo).

Determination of DNA degradation:

To label bacterial DNA, exponentially growing cells at 3 hours after inoculation in TSB were exposed to $\left[{ }^{3} \mathrm{H}\right]$ thymidine $(0.5 \mu \mathrm{Ci} / \mathrm{ml})$ for 2 hours at $37^{\circ} \mathrm{C}$, then collected by centrifuga- 
tion, washed three times with fresh TSB and reincubated in the same medium containing a 100fold concentration of unlabeled thymidine for an additional 30 minutes. For determination of the NCS-induced DNA degradation, NCS $(50 \mu \mathrm{g} / \mathrm{ml})$ was added to the $\left[{ }^{3} \mathrm{H}\right]$ thymidine-labeled cells $\left(1 \sim 2 \times 10^{8}\right.$ cells $\left./ \mathrm{ml}\right)$. Samples were removed at 15 -minute intervals, chilled rapidly, and cold trichloroacetic acid (TCA) was added to $10 \%$ with $1 \mathrm{mg}$ bovine serum albumin. The TCA-precipitate was collected on a glass fiber paper (type GB-100, Toyo) and washed with $10 \%$ TCA, then successively with ethanol and diethyl ether. Radioactivity of the paper was determined in a Packard liquid scintillation spectrometer with $10 \mathrm{ml}$ of scintillation fluid containing $4 \mathrm{~g}$ of 2,5-diphenyloxazole and $2 \mathrm{mg}$ of 1,4-bis-[2-(5-phenyloxazol)]-benzene in 1 liter of toluene.

Sedimentation analysis of DNA in neutral and alkaline sucrose gradients:

The method of MCGRATH et al. ${ }^{\text {) }}$ was used for sedimenting DNA in neutral or alkaline sucrose density gradients. Spheroplasts were produced by the addition of lysozyme $(50 \mu \mathrm{g} / \mathrm{ml})$ and EDTA (1 mM) to B. subtilis cells suspended in $0.02 \mathrm{M}$ Tris- $\mathrm{HCl}(\mathrm{pH} 7.2)$ containing $20 \%$ sucrose, and then lysed with $1 \%$ sodium dodecyl sulfate (SDS). The lysate $(0.4 \mathrm{ml})$ was placed on the top of a $5 \sim 20 \%$ (w/v) neutral sucrose gradient in $0.02 \mathrm{M}$ Tris- $\mathrm{HCl}, 0.15 \mathrm{M} \mathrm{NaCl}$ and $1 \mathrm{~mm}$ EDTA ( $\mathrm{pH} 7.0$ ) or on the top of an alkaline sucrose gradient in $0.25 \mathrm{M} \mathrm{NaOH}, 0.15 \mathrm{M}$ $\mathrm{NaCl}$ and $1 \mathrm{~mm}$ EDTA. These gradients were centrifugated at 40,000 rev./min (Hitachi RPS $65 \mathrm{TA}$ roter) for 90 minutes at $18^{\circ} \mathrm{C}$, and 7 drop fractions were collected on glass fiber papers for radioactivity determination.

Isolation of cell membrane-DNA complex:

The method described by EARHART et al. ${ }^{7)}$ was used to obtain cell membrane-DNA complex (M-band). Briefly, the spheroplasts were harvested by centrifugation and resuspended in $1 \mathrm{ml}$ of cold TKM buffer $(0.01 \mathrm{M}$ Tris- $\mathrm{HCl}, 0.01 \mathrm{~m}$ magnesium acetate and $0.1 \mathrm{M} \mathrm{KCl}, \mathrm{pH} 7.2)$. Three-tenth $\mathrm{ml}$ of the spheroplast suspension and $0.1 \mathrm{ml}$ of $0.4 \%$ sodium $\mathrm{N}$-lauroyl sarcosinate was layered on a $4.6 \mathrm{ml} 15 \sim 45 \%$ (w/v) sucrose gradient in TKM buffer. The layered spheroplasts and detergent were carefully mixed in order to facilitate the formation of $\mathrm{Mg}$-sarkosyl crystals. The gradient was centrifugated at 15,000 rev./min (Hitachi RPS 40 roter) for 20 minutes at $4^{\circ} \mathrm{C}$. Eight drop fractions were collected from the top of the tube on the glass fiber papers for radioactivity determination.

\section{Results}

\section{NCS-induced Degradation of DNA in B. subtilis}

B. subtilis cells, which had been labeled with $\left[{ }^{3} \mathrm{H}\right]$ thymidine for 2 hours and then chased with unlabeled thymidine for 30 minutes, were exposed to $50 \mu \mathrm{g} / \mathrm{ml}$ of NCS and the degradation of $\left[{ }^{3} \mathrm{H}\right]$-labeled DNA into acid-soluble materials was determined at various intervals. As shown in Fig. 1, DNA degradation started within 15 minutes after the addition of NCS and about $7 \%$ of the total cellular DNA was degraded very rapidly within 30 minutes. Then the second step of degradation started which degraded $54 \%$ of DNA in 4 hours after exposure of the cells to NCS. About $40 \%$ of the label in DNA remained undegraded, however, even when the NCS-treatment was prolonged for 8 hours. Chloramphenicol added simultaneously with NCS stimulated the degradation of DNA.

The results obtained with $B$. subtilis differed from those with $S$. lutea in that the induction of DNA degradation in $B$. subtilis required higher concentrations $(>50 \mu \mathrm{g} / \mathrm{ml})$ of NCS and longer induction period ( $>15$ minutes) and that the degradation was stimulated by chloramphenicol which prevented the NCS-induced DNA degradation in S. lutea ${ }^{5)}$.

\section{Preferential Breakdown of Nascent DNA into Acid-soluble Materials}

Among the agents known to cause DNA degradation, nalidixic acid is known to initiate the degradation at the growing point of DNA to older DNA ${ }^{8)}$. To test if the NCS-induced 
Fig. 1. NCS-induced DNA degradation in $B$. subtilis and the effect of chlorampenicol on the degradation.

Exponentially growing prelabeled $\left(\left[{ }^{3} \mathrm{H}\right]\right.$ thymidine) B. subtilis was exposed to NCS $(50 \mu \mathrm{g} / \mathrm{ml})$ as described in Materials and Methods. The radioactivity in the acid-insoluble fraction was determined at the times indicated in the figure.

Symbols: (a), untreated control; (b), NCS alone, $50 \mu \mathrm{g} / \mathrm{ml}$; (c), chloramphenicol alone, $100 \mu \mathrm{g} / \mathrm{ml}$; (d), chloramphenicol $(100 \mu \mathrm{g} / \mathrm{ml})$ and NCS $(50 \mu \mathrm{g} / \mathrm{ml})$ were added simultaneously at 0 time; (e), chloramphenicol $(100 \mu \mathrm{g} / \mathrm{ml})$ was added at 30 minutes before exposure of the cells to NCS $(50 \mu \mathrm{g} / \mathrm{ml})$ at 0 time; (f), chloramphenicol $(100 \mu \mathrm{g} / \mathrm{ml})$ was added at 1 hour (arrow) after exposure of the cells to NCS $(50 \mu \mathrm{g} / \mathrm{ml})$ at 0 time.

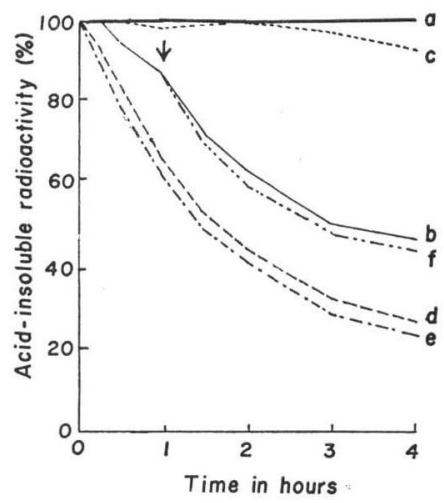

Table 1. NCS-induced DNA degradation in the double-labeled cells

B. subtilis cells were first labeled with $\left[{ }^{14} \mathrm{C}\right]$ thymidine for 5 minutes. After chasing with unlabeled thymidine for 15 minutes, the cells were labeled with $\left[{ }^{3} \mathrm{H}\right]$ thymidine for another 5 minutes. The double-labeled cells were exposed to NCS $(50 \mu \mathrm{g} / \mathrm{ml})$ for indicated periods of time. The radioactivities of $\left[{ }^{14} \mathrm{C}\right]$ and $\left[{ }^{3} \mathrm{H}\right]$ remaining in the acid-insoluble fraction of the cells treated or untreated with NCS were determined.

\begin{tabular}{c|c|c|c|c}
\hline \multirow{2}{*}{$\begin{array}{c}\text { Incubation } \\
\text { time } \\
\text { (min) }\end{array}$} & \multicolumn{3}{|c}{$\begin{array}{c}\text { Radioactivity in acid-insoluble } \\
\text { fraction }(\%)\end{array}$} \\
\cline { 2 - 5 } & ${ }^{3} \mathrm{H}$ & ${ }^{14} \mathrm{C}$ & ${ }^{3} \mathrm{H}$ & ${ }^{14} \mathrm{C}$ \\
\cline { 2 - 5 } & 100 & 100 & 100 & 100 \\
\hline 0 & 104 & 107 & 61.9 & 85.7 \\
30 & 97.1 & 97.6 & 20.6 & 81.5 \\
60 & 97.0 & 97.2 & 12.6 & 76.3 \\
90 & 90.0 & 95.4 & 10.7 & 69.7 \\
120 & 90.4 & & & \\
\hline
\end{tabular}

DNA degradation proceeds in a similar manner, the following experiments were conducted. Experiment $1 \mathrm{~B}$. subtilis cells were first labeled with $\left[{ }^{14} \mathrm{C}\right]$ thymidine $(0.2 \mu \mathrm{Ci} / \mathrm{ml})$ for 5 minutes at $37^{\circ} \mathrm{C}$, then washed and resuspended in a prewarmed fresh medium contain-

ing unlabeled thymidine. After 15 minutes of incubation, the cells were washed and resuspended in the prewarmed medium. To the culture $\left[{ }^{3} \mathrm{H}\right]$ thymidine $(0.2 \mu \mathrm{Ci} / \mathrm{ml})$ was added, and 5 minutes later the cells were again washed and resuspended in the prewarmed fresh medium containing unlabeled thymidine. These double-labeled cells were then exposed to $50 \mu \mathrm{g} / \mathrm{ml}$ of NCS and both the $\left[{ }^{14} \mathrm{C}\right]$ - and $\left[{ }^{3} \mathrm{H}\right]$-label which remaining in the acid-insoluble fractions were determined (Table 1). In the cells exposed to NCS, the amount of acid-insoluble $\left[{ }^{3} \mathrm{H}\right]$-label decreased more rapidly than that of $\left[{ }^{14} \mathrm{C}\right]$-label. Thus, the nascent DNA was degraded more rapidly than the older DNA upon exposure of the cells to NCS.

Experiment 2 The cells were labeled with $\left[{ }^{3} \mathrm{H}\right]$ thymidine $(0.2 \mu \mathrm{Ci} / \mathrm{ml})$ for 5 minutes, then chilled, and washed twice with cold medium, and resuspended in a prewarmed fresh medium containing unlabeled thymidine. The cell suspension was divided into four equal portions and each portion was incubated at $37^{\circ} \mathrm{C}$ in the absence of NCS for $0,15,30$ and 45 minutes, respectively, before exposure to $50 \mu \mathrm{g} / \mathrm{ml}$ of NCS. The radioactivity remaining in the acid-insoluble fraction was determined after exposure of the cells to NCS for 60 minutes (Table2). It was found that the longer the chasing period, the more radioactive DNA remained.

We concluded from these two experiments that the NCS-induced DNA degradation initiates at region near the growing point of DNA. 
Table 2. NCS-induced DNA degradation in the pulse-labeled cells

B. subtilis cells were labeled with $\left[{ }^{3} \mathrm{H}\right]$ thymidine for 5 minutes, washed and chased in the presence of unlabeled thymidine for $0,15,30$ and 45 minutes, then exposed to NCS for 60 minutes, the radioactivities in acid-insoluble fractions were determined.

\begin{tabular}{c|c|c}
\hline \multirow{2}{*}{$\begin{array}{c}\text { Incubation } \\
\text { time after } \\
\text { pulse label } \\
\text { (min) }\end{array}$} & $\begin{array}{c}\text { Radioactivity in acid-insoluble } \\
\text { fraction }(\%)\end{array}$ \\
\cline { 2 - 3 } & Control & NCS-treated \\
\hline 0 & 100 & 18.9 \\
15 & 105 & 29.0 \\
30 & 101 & 44.2 \\
45 & 98.0 & 57.0 \\
\hline
\end{tabular}

NCS-induced Dissociation of DNA from the Cell Membrane

It is believed that the bacterial DNA attaches to the cell membrane at the initiation and growing point $t^{\theta, 10)}$. Therefore, the preferential breakdown of growing region induced by NCS might cause the detachment of the bacterial DNA from the membrane. To test this idea, we isolated from the NCS-treated cells the so called "M-band" where DNA is known to be associated with membrane ${ }^{7,11)}$. To do this, the cells which had been labeled with $\left[{ }^{3} \mathrm{H}\right]$ thymidine were exposed to $50 \mu \mathrm{g} / \mathrm{ml}$ of NCS for 5, 20 and 40 minutes, then harvested by centrifugation and resuspended in $1 \mathrm{ml}$ of TKM buffer. The cell suspension was mixed with sarkosyl on the top of a $15 \sim 45 \%$ sucrose gradient and centrifuged at 15,000 rev./min (Hitachi RPS 40 roter) for 20 minutes. As shown in Fig. 2, when the cells were untreated with NCS, over $90 \%$ of labeled DNA was recovered in an Mband zone $(20 \sim 24$ th fractions) which isopycnically banded at a sucrose concentration of $30 \%$. The amount of DNA associated with the M-band was unchanged at 5 minutes after exposure of the cells to $50 \mu \mathrm{g} / \mathrm{ml}$ of NCS, while after 20 and 40 minutes it decreased to 60 and $70 \%$ of the untreated control, respectively.

The labeled DNA (or its breakdown products) dissociated from the M-band remained in the top fractions of the gradient under these centrifugal conditions. To examine whether the labeled materials in the top fractions ( $1 \mathrm{st} \sim 5$ th fractions) still possessed a macromolecular structure, the top fractions were pooled, then sedimented again in a $15 \sim 45 \%$ sucrose gradient. It was found that about $75 \%$ of the labeled materials was sedimented toward the bottom of the gradient after centrifugation for 7 hours (sedimentation coeff., $>50-\mathrm{S}$ ). This fact indicated that the majority of DNA dissociated from the membrane was macromolecular in nature. We concluded that the NCS-induced degradation of the regions near the growing point of DNA resulted in the release of DNA molecules from their attachment site on the cell membrane. 
NCS-induced Single- and Double-strand Scissions in DNA

In order to examine the processes by which the DNA detached from membrane is further degraded, $\left[{ }^{3} \mathrm{H}\right]$ thymidine-labeled cells were exposed to $50 \mu \mathrm{g} / \mathrm{ml}$ of $\mathrm{NCS}$ at $37^{\circ} \mathrm{C}$ for $30,40,90$, 120 and 150 minutes, and then the DNA was analyzed for molecular size by sedimentation in neutral and alkaline sucrose gradients. In these experiments analysis was made with the DNA obtained by direct lysis of spheroplasts with SDS as well as the DNA obtained by the M-band method in order to minimize artifacts due to hydrodynamic shearing of DNA.

Fig. 3. Neutral sucrose gradient analysis of the DNA from B. subtilis exposed to NCS.

Sedimentation analysis was performed as described in Materials and Methods.

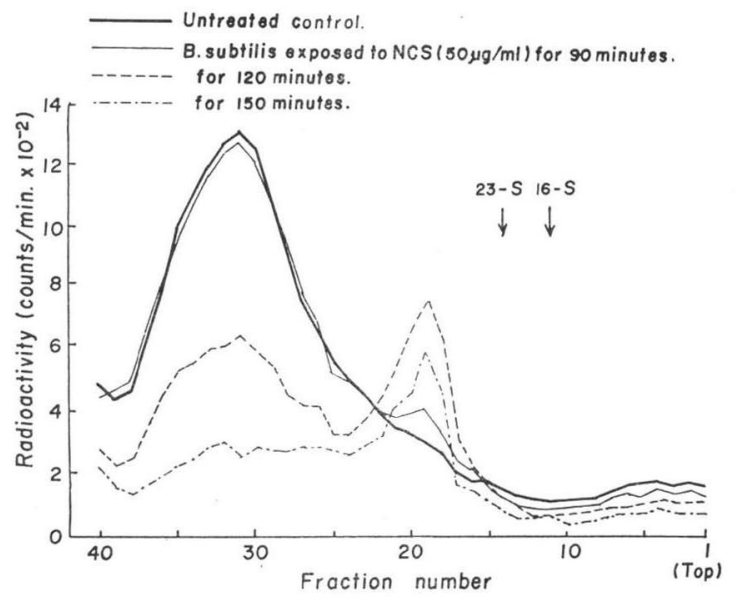

Fig. 4. Alkaline sucrose gradient analysis of the DNA from B. subtilis exposed to NCS.

Sedimentation analysis was performed as described in Materials and Methods.

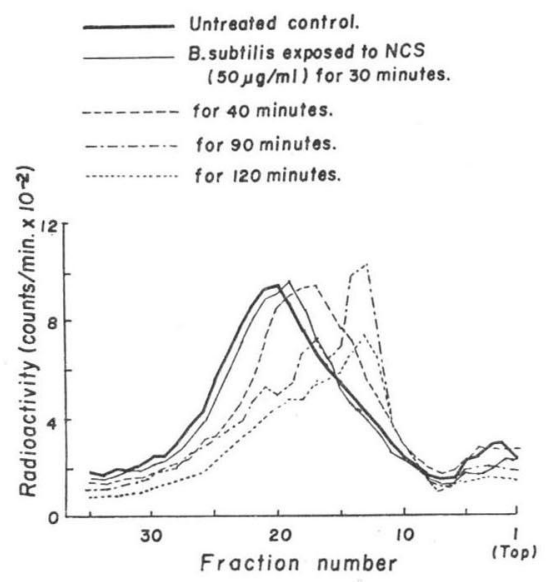

As shown in Fig. 3, DNA from the cells untreated with NCS sedimented in a band with a peak at the 30th fraction which corresponded to approximately 50-S as estimated from marker $E$. coli ribosomal RNAs. When the cells were treated with NCS no significant change was seen at 40 minutes, while at 90 minutes an additional peak appeared at the 20th fraction (approx. $30-\mathrm{S}$ ) and the amount of $30-\mathrm{S}$ material relative to that of $50-\mathrm{S}$ increased with time. No distinct peak of intermediary sizes appeared in several repeated experiments. The results suggest that the bacterial DNA was split in a specific manner after detachment from membrane thereby yielding DNA fragments of a single size.

These DNA preparation were also analyzed by sedimentation in alkaline sucrose gradients (Fig. 4). The alkali-denatured, single-stranded DNA from untreated control cells sedimented in a broad band with a peak at the 20th fraction. When the cells were exposed to NCS for 30 minutes, the DNA band slightly shifted toward the top of the gradient with a peak at the 19 th fraction. This shift in peak position gradually became more evident as the time of NCS-treatment increased. The results indicate that the single-strand breaks of DNA become detectable in 30 minutes after the addition of NCS, at the time when double-strand break was not detectable (Fig. 3). Moreover, the denatured breakdown products of DNA which were banded with a peak at the 13th fraction in the sample treated for 90 minutes remained unchanged without further degradation during prolonged incubation with NCS. We concluded from these results that single-strand nicking preceded the double-strand breaks in DNA, and that 
both the single- and double-strand breaks apparently ceased when DNA was broken to doublestranded fragments of about 30-S

Effect of Chloramphenicol on the NCS-induced Breakdown of DNA

The degradation of DNA in B. subtilis into acid-soluble form was stimulated by chloramphenicol, the extent of DNA degradation reaching $80 \%$ of total DNA (Fig. 1). We therefore examined whether chloramphenicol stimulated the NCS-induced endonucleolytic break of bacterial DNA as well as the degradation into acid-soluble form. First, to test the effect of single treatment with chloramphenicol, $\left[{ }^{3} \mathrm{H}\right]$ thymidine-labeled cells were exposed to chloramphenicol $(100 \mu \mathrm{g} / \mathrm{ml})$ for 120 minutes, and DNA was sedimented in the neutral sucrose gradient. As shown in Fig. 5A, the sedimentation profile of such DNA was indistinguishable from that of untreated control. When the cells were exposed to $50 \mu \mathrm{g} / \mathrm{ml}$ of NCS in the presence of chloramphenicol $(100 \mu \mathrm{g} / \mathrm{ml})$ for 120 minutes, the DNA distributed broadly in the gradient without any distinct peak. When the same DNA preparation was analyzed in the alkaline sucrose gradient, no distinct peak was seen at the 13th fraction and a large amount of radioactivity distributed toward the top of the gradient (Fig. 5B). These results indicated that chloramphenicol stimulated the NCS-induced endonucleolytic breakdown of DNA resulting in the further degradation of the DNA fragments of 30-S which otherwise were the major final degradation products of DNA in the NCS-treated cells.

\section{Discussion}

It was found that when logarithmically growing B. subtilis cells were exposed to NCS, cellular DNA was degraded into an acid-soluble form. Processes of the NCS-induced DNA degradation in $B$. subtilis may be divided into the following five stages. (1) Degradation of DNA at the regions near the growing point, (2) detachment of DNA from its attachment site on the cell membrane, (3) single-strand breaks in the detached DNA duplex, (4) DNA breakdown into double-stranded fragments (30-S), (5) concomitant endonucleolytic breakdown of double-stranded fragments into an acid-soluble form that starts in about 15 minutes after the addition of NCS.

The NCS-induced DNA degradation in B. subtilis was found to differ from that in S. lutea in three points, ${ }^{45}$. First, the degradation in B. subtilis required a longer induction period ( $>15$ minutes) and relatively high concentrations $(>50 \mu \mathrm{g} / \mathrm{ml})$ of NCS (Fig. 1), while that in $S$. lutea was detectable within 5 minutes after exposure of the cells to $0.5 \mu \mathrm{g} / \mathrm{ml}$ of NCS. Second, NCS caused the degradation of $45 \%$ of the cellular DNA in 3 hours and reached a plauteau at about $60 \%$ in B. subtilis, whereas in S. lutea about $80 \%$ of the cellular DNA was degraded into acid-soluble form within 3 hours at $0.5 \mu \mathrm{g} / \mathrm{ml}$ of NCS. Third, the degradation in $B$. subtilis was stimulated by chloramphenicol which prevented the NCS-induced DNA degradation in $S$. lutea.

The specific regions in the bacterial DNA sensitive to the action of NCS were found. NCS caused preferential breakdown of DNA at the regions near the growing point and the degradation proceeded sequentially from the nascent regions of DNA to older DNA (Tables 1 and 2). From this finding, we presumed that the bacterial DNA might detach from its attachment site on the cell membrane at early stages of NCS action, because it is known that the bacterial DNA attaches to the cell membrane at its initiating and growing points ${ }^{9,10)}$, and this supposition was tested by using the M-band technique ${ }^{8)}$. We found that the DNA detached from M-band within 20 minutes after the addition of NCS (Fig. 2) (no mechanical detachment was detacted in control experiments without NCS-treatment $t^{12)}$ ). At this stage, the majority of DNA detached from M-band was macromolecular in nature and about $4 \%$ of total cellular DNA was degraded 
into an acid-soluble form. This initial degradation of DNA into the acid-soluble form corresponded in amount to the degradation of DNA at the regions near the growing point. We concluded from these results that the degradation of DNA at the regions near the growing point resulted in the detachment of DNA from membrane.

On the other hand, sedimentation analysis of the DNA revealed that single- and doublestrand breaks in DNA became detectable in 30 and 90 minutes, respectively, after exposure of the cells to NCS. Furthermore, we found that such nicking of double-strands eventually gave rise to the accumulation of fragments of a single-size class (Figs. 3 and 4). From these facts, we concluded that the bacterial DNA is split in a specific manner into double-stranded fragments after the detachment of DNA from membrane.

Fig. 5. The effect of chloramphenicol on the endonucleolytic breakdown of DNA induced by NCS.

The experiments were carried out in the same way as described in the legend to Fig. 3 and Fig. 4. (A), Neutral and (B), alkaline sucrose gradient analysis of DNA. Incubation was for 120 minutes.
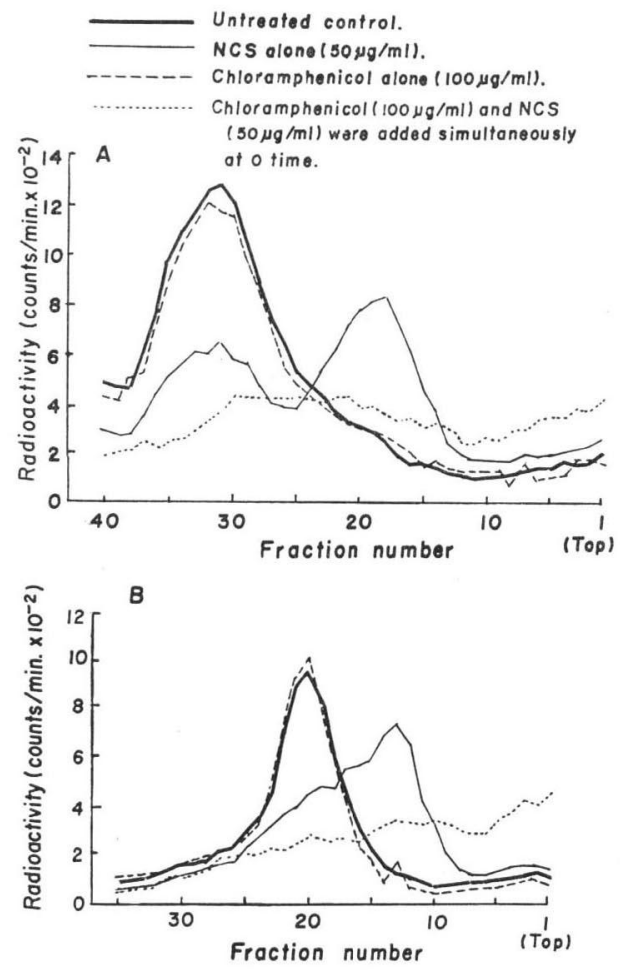

In contrast to the result with $S$. lutea $a^{5)}$, the endonucleolytic nicking induced by NCS as well as the degradation into acid-soluble form was stimulated by the simultaneous addition of chloramphenicol. The sedimentation profiles in both neutral and alkaline sucrose gradients of the cells treated simultaneously with NCS and chloramphenicol were more broad than those of the cells treated with NCS alone, and no distinct peak of the final DNA product of endonucleolytic breakdown was observed (Figs. 5A and 5B). Thus, chloramphenicol apparently stimulated the NCS-induced endonucleolytic breakdown of DNA resulting in the further degradation of these DNA fragments. We found, in HeLa S3 cells, that the breaks in single-strand of DNA induced by NCS were repaired during the subsequent incubation for 24 hours at $37^{\circ} \mathrm{C}$ in the absence of NCS, and the repair reaction was inhibited by puromycin (unpublished result). Although such repair process has not been confirmed in the bacterial system due to technical difficulties, it is likely that the stimulation of DNA degradation by chloramphenicol in the NCS-treated B. subtilis is due to the inhibition of the repair process of DNA in which synthesis of new protein(s) is involved $^{13)}$. This inhibition of repair might have resulted in the further degradation of DNA fragments which are otherwise the end products.

The mode of double-strand breaks of DNA induced by NCS is similar to that induced by mitomycin $C$ in $B$. subtilis $168^{14,15)}$. Since NCS is known to induce active $\lambda$-phage in lysogenic $E$. coli ${ }^{10,17)}$ and a certain strain of phage in B. subtilis W-23 strain (unpublished data), it is conceivable that phage induction by NCS in B. subtilis is a consequence of the double-strand scission in the bacterial DNA.

\section{Acknowledgments}

We thank Dr. Y. Koyama, Kayaku Antibiotics Research Co., for the gift of neocarzinostatin. 
We are grateful to Drs. Y. ONO and Y. WATANABE for their helpful discussions and efforts in the revision of the manuscript. These studies were supported in part by grants from the Japanese Ministry of Education.

\section{References}

1) Ishida, N.; K. Miyazaki \& M. Rikimaru: Neocarzinostatin, an antitumor antibiotic of high molecular weight. J. Antibiotics, Ser. A 18: 68 76, 1965

2) Meienhofer, J.; H. Maeda, C. B. Glaster, J. Czombos \& K. Kuromizu: Primary structure of neocarzinostatin, an antitumor protein. Science 178: 875 876, 1972

3) Ono, Y.; Y. WAtanabe \& N. Ishida: Mode of action of neocarzinostatin. Inhibition of DNA synthesis and degradation of DNA in Sarcina lutea. Biochim. Biophys. Acta 119: 46 58, 1966

4) Homma, M.; T. Koide, T. Saito-Koide, I. Kamo, M. Seto, K. Kumagai \& N. Ishida: Specific inhibition of the initiation of DNA synthesis in HeLa cells by neocarzinostatin. Proc. 6th Internat. Congr. Chemotherapy. Vol. II. pp. 410 415, University of Tokyo, Tokyo, 1969

5) Ono, Y.; Y. Ito, H. MAedA \& N. IshidA: Mode of action of neocarzinostatin. Requirement of protein synthesis for neocarzinostatin-mediated DNA degradation in Sarcina lutea. Biochim. Biophys. Acta 155: 616 618, 1968

6) McGrath, R. G. \& R. W. Williams: Reconstruction in vivo of irradiated Escherichia coli deoxyribonucleic acid; the rejoining of broken pieces. Nature 212: 534 535, 1966

7) Earhart, C.F.; G. Y. Tremblay, M. J. Daniels \& M. Schechter: DNA replication studied by a new method for the isolation of cell membrane-DNA complexes. Sympos. Quant. Biol. 33: $707 \sim 710,1968$

8) Ramareddy, G. \& H. Reiter: Specific loss of newly replicated deoxyribonucleic acid in nalidixic acid-treated Bacillus subtilis 168. J. Bact. 100: 724 729, 1969

9) Ganesan, A. T. \& J. Lederberg: A cell-membrane bound fraction of bacterial DNA. Biochem. Biophys. Res. Commun. 18: 824 835, 1965

10) Sueoka, N. \& W. G. QuinN: Membrane attachment of the chromosome replication origin in Bacillus subtilis. Sympos. Quant. Biol. 33: 695 705, 1968

11) Frrshern, W.: The DNA/membrane fraction of pneumococcus contains a DNA replication complex. J. Mol. Biol. 70: 383 397, 1972

12) Yamada, M. \& F. HANAOKA: Periodic changes in the association of mammalian DNA with the membrane during the cell cycle. Nature, New Biol. 243: 227 230, 1973

13) Kitayama, S. \& A. Matsuyama: Possibility of the repair of double-strand scissions in Micrococcus radiodurans DNA caused by gamma-rays. Biochem. Biophys. Res. Commun. 33: 418 422, 1968

14) Окамото, K; J. A. Mudd, J. Mangan, W. M. Huang, T. V. Subbaitah \& J. Marmur: Properties of the defective phage of Bacillus subsilis. J. Mol. Biol. 34: 413 428, 1968

15) Okamoto, K.; J. A. Mudd \& J. Marmur: Conversion of Bacillus subtilis DNA to phage DNA following mitomycin C induction. J. Mol. Biol. 34: 429 437, 1968

16) Heinemann, B. \& A. HowARD: Induction of LAMBDA-Bacteriophage in Escherichia coli as screening test for potential antitumor agents. Appl. Microbiol. 12: 234 239, 1964

17) Price, K. E.; R. E. Buck \& J. LeIN: System for detecting inducers of lysogenic Escherichia coli W 1709 (lambda) and its applicability as a screen for antineoplastic antibiotics. Appl. Microbiol. 12: $428 \sim 435,1964$ 